\title{
Determinants of E-Learning Acceptance: An Empirical Study in the Tunisian Context
}

\author{
Bouzaabia Rym ${ }^{1}$, Bouzaabia Olfa ${ }^{2 *}$, Ben M'Barek Mélika ${ }^{3}$ \\ ${ }^{1}$ Department of Marketing, Institute of High Business Studies of Sousse, University of Sousse, Sousse, Tunisia; ${ }^{2}$ Faculty of Eco- \\ nomic Sciences and Management of Tunis, University of Tunis El Manar, Tunis, Tunisia; ${ }^{3}$ Faculty of Economic Sciences and Man- \\ agement of Tunis, University of Tunis El Manar, Tunis, Tunisia. \\ Email: rymb060@gmail.com, *olfabouzaabia@yahoo.fr,melikabm@gmail.com
}

Received February $1^{\text {st }}, 2013$; revised March $24^{\text {th }}, 2013$; accepted April $20^{\text {th }}, 2013$

Copyright (C) 2013 Bouzaabia Rym et al. This is an open access article distributed under the Creative Commons Attribution License, which permits unrestricted use, distribution, and reproduction in any medium, provided the original work is properly cited.

\begin{abstract}
This study proposes to identify the determinants of accepting e-learning by the employees of the Tunisian Post Office using the Technology Acceptance Model (TAM). An empirical study was conducted over a sample of 200 Tunisian employees. Our results indicated that for the Tunisian employees perceived usefulness, perceived ease of use, mastery of new information and communication technologies (NICT) as individual factors as well as the proposed technique as an organisational factor represented the main determinants of e-learning acceptance.
\end{abstract}

Keywords: E-Learning; Technology Acceptance Model; Tunisian Context; Structural Equation Modeling

\section{Introduction}

The emergence and evolution of the Internet have led to the development of useful and powerful tools for distance learning. As a result, e-learning is becoming increasingly important and is making the learning process more effec- tive in many contexts [1].

Education and industry have sought the contribution of e-learning in order to improve their competitivity [2], financially, socially and organisationally. Finance-wise, e-learning allows for reducing total training costs by eliminating various transportation and accommodation fees which sometimes exceed half of the total costs $[3,4]$. Organisation-wise, e-learning creates new individual training platforms, favours group training within virtual teams and prepares knowledge management thanks to electronic interactions which reinforce group and cooperative work [5]. Socially speaking, thanks to its permanent and participatory potentials, e-learning may be perceived by employees as a "strong social act that generates in them better behaviour at work" [6]. Despite these advantages, recourse to e-learning is not often accepted by end users. We notice that users are often unwilling to opt for e-learning even if this latter may generate significant increases in productivity [7]. The reasons seem to be subtle and exceed rational decisions traditionally recom-

\footnotetext{
"Corresponding author.
}

mended by the economic approach.

It would be then interesting to determine the factors that influence the implementation of e-learning among the training practices of Tunisian firms. Understanding determinants of e-learning adoption assumes the analysis of the manner with which trainees perceive, express and use this training technique.

Then, our study aims at determining the factors behind accepting e-learning by trainees. To this effect, we use a very well defined model, which is the Technology Acceptance Model (TAM), to conduct an empirical study over 200 employees of the Tunisian Post Office across the different regions of Sfax, Sousse, Tunis, Monastir and Jendouba to test our hypotheses.

In the first section, we present the review of the literature. In the second section, we present our research hypotheses. The third section discusses our methodology. Finally, the results of our research are presented and discussed in the last section.

\section{Literature Review}

\subsection{Definition of E-Learning}

E-learning generally refers to methods of learning which use electronic instructional content delivered via the internet and is a term which is synonymous with Webbased or online learning [8]. The widespread prolifera- 
tion of internet technologies and applications provides incredible opportunities for the delivery of education and training. Moreover, with rapidly increasing internet usage e-learning has now become a portable and flexible new method for learners to gain essential knowledge [8]. Nowadays e-learning is emerging as a new paradigm of modern education, especially for small and mediumsized enterprises [9].

Many empirical studies support the idea that effective e-learning benefits organization success [10]. That is why e-learning plays such an important role in organizational training.

E-learning can be classified as asynchronous e-learning or synchronous e-learning $[11,12]$. First asynchronous e-learning is a form of self-study [13] commonly facilitated by media such as email and discussion groups; supports work relationships among learners with teachers, even when participants cannot be online at the same time. As such, it is a key component of flexible e-learning [14]. In contrast synchronous e-learning allows for real-time interaction and just-in-time response between instructors and learners [15] commonly supported by media such as videoconferencing and chat. It has a potential to support e-learners in the development of learning communities [14].

According to Favier et al. [16], the main stakeholders in an e-learning platform are learners, teachers-tutors, but also the institution in which the project takes place. These are the three areas of performance of e-learning [17]. E-learning provides for learners several advantages [18-20]:

- Ease of learning with better retention: E-learning offers to learners the opportunity of an easy access to relevant and useful knowledge [21-24]). Collins et al. [21] argue from them that "e-learning" enhances information storage rate.

- Flexibility of time and place: e-learning gives students the opportunity to attend training at anytime, anywhere [25]; this is the "Just in time" approach $[19,26]$.

- Customizing e-learning: "e-learning" allow learners to learn according to their individual pace and according to their personal agendas [11,26,27].

- Improving Productivity: E-learning offers opportunities to improve and increase learners' effectiveness $[21,23]$.

- Interactivity and institution-community collaboration: e-learning binds each learner with other learners and experts together to form a collaborative learning community $[11,21,26]$.

However, these assumptions are not shared by all researchers $[28,29]$ and are dependent on the acceptance of e-learning technologies for learners, which is linked to a number of contextual factors.

\subsection{The Technology Acceptance Model}

The technology acceptance model was introduced by Davis [30] as an adaptation of the theory of reasoned action to model user acceptance of information systems. Its purpose is to explain the determinants of the acceptance of the use of computers and related technologies in a wide range of technologies and user groups. TAM has been made to trace the impact of external factors on the beliefs, attitudes and intentions by identifying a limited number of variables suggested by previous research regarding the cognitive and emotional determinants of accepting the computer and using TRA as the theoretical foundation for modeling the theoretical relationships between these variables.

TAM explains the acceptance of information technology in performing tasks and identifies perceived usefulness (PU) and perceived ease of use (PEOU) as two key determinants that enhance the use of technology [2]. Davis [30] offers the following definitions of the two key concepts of the model:

- Perceived usefulness is "the degree to which a person believes that using a particular system would enhance his job performance" [30].

- Ease of use refers to "the degree to which a person believes that using a particular system would be free of effort" [30].

"According to the TAM, both PU and PEOU influence the attitude of individuals towards the use of a particular technology, while attitude and PU predict the individual's behavioural intention (BI) to use the technology" [13]. PU is influenced by PEOU, because, other things being equal, the easier a technology is to use, the more useful it will be [31]. "PU is also influenced by PEOU. TAM also suggests that external variables intervene indirectly, influencing both PU and PEOU" [13].

Davis model is presented as the Figure 1 shows.

\subsection{Extended TAM}

TAM has been the subject of several applications and has been shown to be a significant predictor in a variety of studies. Venkatesh and Davis [32] examined the impact of gender on the acceptance of technology and have concluded that gender is a fundamental aspect of culture and it can affect the process of technology adoption.

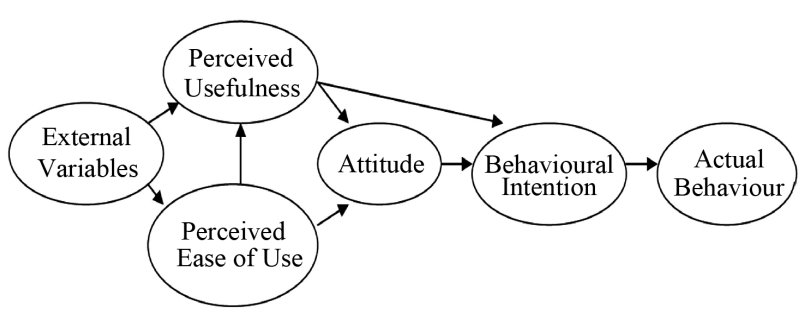

Figure 1. Technology acceptance model. 
Mathieson [33] compared TAM and theory of planned behaviour and noted that both provide a good explanation of intention. However, while TAM is the easiest to apply, it provides only general information about the views of technology users. Mathieson [33] postulates that the key concepts of TAM remain insufficient to predict intention to use, and those other variables, equally powerful and meaningful, should be incorporated into the model.

Moreover, the fact that TAM in its first version has evaded subjective norms has been criticized. Thompson [34] showed that the addition of an appropriate social factor increases its predictive value. For their part, Venkatesh and Davis [32] assume that the first version of TAM lacks pragmatic usefulness because it does not explain the factors of each concept of the model.

In this paper an extended model is proposed, based on an extension of the TAM approach. The extended model includes constructs and relationships which may prove to be important in the context of e-learning. These constructs are: Social factors; System factors; Individual factors organizational factors and Voluntariness of use factors.

\section{Research Model and Hypotheses}

Our research design was inspired by the model of technology acceptance and various extensions and modifications made to this model $[15,32,33]$. Four types of factors influence usefulness and perceived ease of use of elearning: Social factors (Interpersonal influences and intrapersonal influences), System factors (content quality), organizational factors (technics assistance) and individual factors (NICT self-efficacy).

Perceived usefulness jointly reacts with perceived ease of use on attitude toward the use of e-learning. The intended use of e-learning is influenced at the same time by attitude towards this behaviour, by interpersonal influences, and perceived usefulness of e-learning.

Finally, voluntariness will have a moderating effect on the relationship between social factors (INI/ EXI) and the intention to use e-learning [35].

Figure 2 shows an operationalization of the extended TAM.

\subsection{Social Factors}

Social factors were tested as subjective norms on behaveioural intention $[8,36,37]$. Subjective norm is defined as 'the person's perception that salient social referents think he/she should or should not perform the behaviour in question' [36]. The referent influence may be the INI (the influence of friends, family members, colleagues, and superiors) $[15,38,39]$ or the EXI (influence of mass media reports, expert opinions and other non-personal information considered by individuals in performing a behaviour [39].

In the context of e-learning, several researchers have affirmed the positive impact of social factors such as INI and EXI on perceived usefulness and intention to use elearning [32]. Furthermore, Hsu and $\mathrm{Lu}$ [40], Lee [8], Van Raaij and Schepers [41], Cheng [15] and Barki

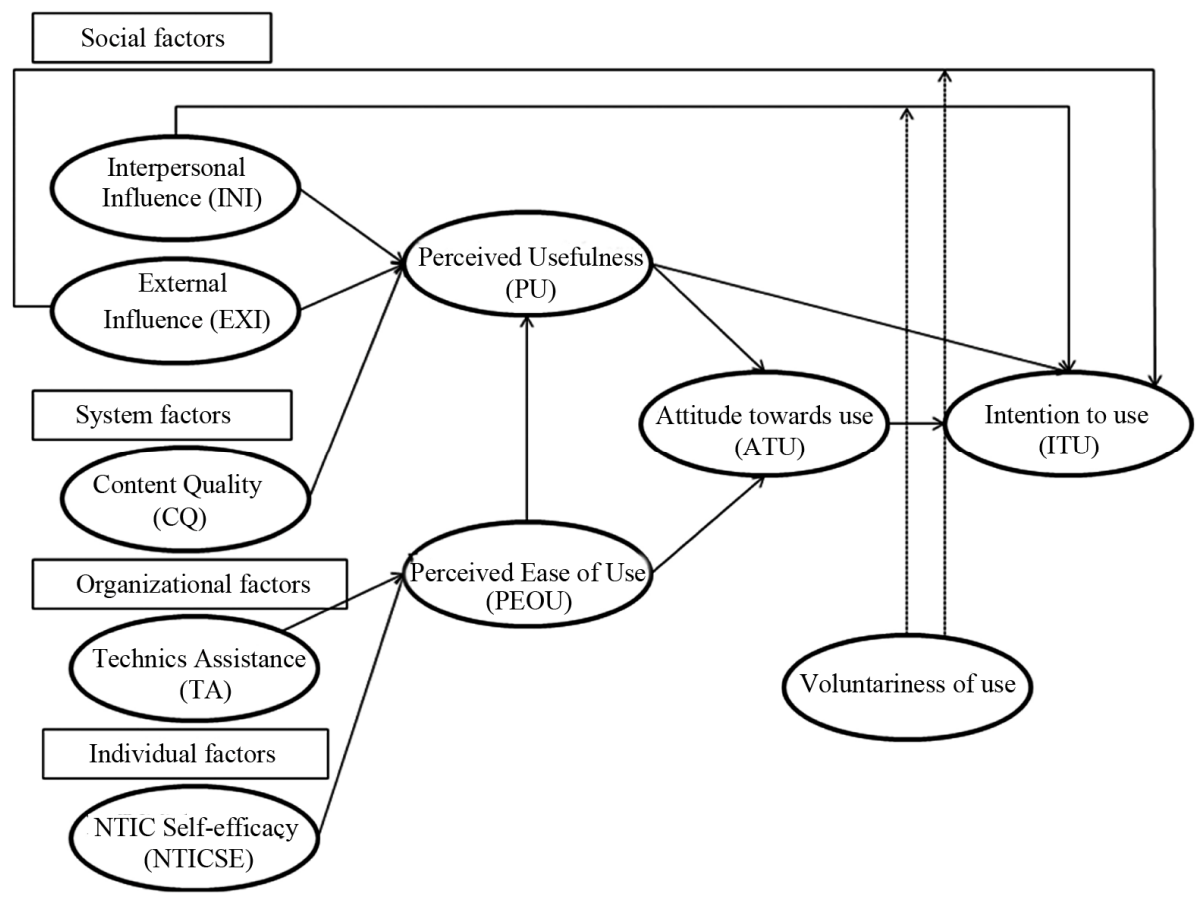

Figure 2. The research model. 
and Hartwick [42] argue that social factors exert a more significant effect on the intention to use technology in the case of mandatory use than in the case of voluntary use. Since the use of e-learning may be voluntary or mandatory, voluntariness is supposed to moderate the relationship between social factors (INI and EXI) and the intention to use e-learning [43]. In other words, in case the company requires its employees to use electronic training, subjective norms play a more important role on the intended use of the method than in the absence of this requirement.

Hence, this study hypothesizes:

- H1A-1: Interpersonal influence will positively affect perceived usefulness of an e-learning system;

- H1A-2: Interpersonal influence will positively affect the intention to use an e-learning system;

- H1B-1: External influence will positively affect perceived usefulness of an e-learning system;

- H1B-2: External influence will positively affect the intention to use an e-learning system;

- H1C: voluntariness has a moderating effect on the relationship between an interpersonal influence and intention to use e-learning;

- H1D: voluntariness has a moderating effect on the relationship between an external influence and intention to use e-learning.

\subsection{Organizational Factor}

\section{Technics Assistance (TA)}

Technics assistance is one of the facilitating conditions for the acceptance of new technologies and more specifically for the use of e-learning [44]. Venkatesh [45] defines facilitating conditions as "the degree to which the user thinks that the organizational and technical infrastructure is required to use the system."

Accordingly, our research tries to assess employees' perceptions of the disposal of their organization to provide help and advice when needed to facilitate the use of e-learning.

Hence, this study hypothesizes:

- H2: Technics assistance will positively affect perceived ease of use of an e-learning system.

\subsection{System Factor}

\section{Content Quality (CQ)}

Lee [8] argues that the content quality in e-learning represents at the same time richness and regular updating of content. The content quality of e-learning is a systemic factor whose positive influence of perceived usefulness of the use of e-learning has been confirmed in several studies $[8,15,46]$.

Hence, this study hypothesizes:

- H3: Content Quality will positively affect perceived of use of an e-learning system.

\subsection{Individual Factors}

\section{NICT Self-Efficacy}

Mastery of a computer refers to forming judgments of a person's self-efficacy to use information technology and communication such as computers, the Internet, intranets, extranets, or emails [35].

Bandura [47] defined self-efficacy as "people's judgments of their capabilities to organize and execute courses of action required to attain designated types of performances. It is concerned not with the skills one has but with the judgments of what one can do with whatever skills one possesses" (p. 391).

In the context of e-learning, several studies have confirmed the positive influence of mastery of new information technology on perceived ease of use [15, 48-50].

Hence, this study hypothesizes:

- H4: NTIC Self-efficacy will positively affect Perceived ease of use of an e-learning system.

\subsection{Determinants of Acceptance: Usefulness, Perceived Ease of Use and Attitude}

We found like Legris et al. [51] and Cheng [15] that most research confirms the presence of significant positive relationships between perceived usefulness, perceived ease of use, attitude and intention to use e-learning.

PU and PEOU directly affect attitude towards using an e-learning system [15,52-54].

PU mediates the influence of PEOU on attitude towards using an e-learning system [15,51-54].

PU directly determines intention to use an e-learning system $[8,15,50,52,54-60]$. Furthermore, PU mediates the influence of PEOU on intention to use the e-learning system [8,16,48,50,52,55-61]. Finally, attitude towards the use of e-learning positively influences intention to use $[15,52]$.

Hence:

- H5: PEOU will positively affect PU of an e-learning system;

- H6: PU will positively affect attitude towards using an e-learning system;

- H7: PU will positively affect the intention to use an e-learning system;

- H8: PEOU will positively affect the attitude towards using an e-learning system;

- H9: Attitude towards using the e-learning system will positively affect the intention to use the system.

\section{Methodology}

\subsection{Sample and Data Collection}

In this research, we conducted a survey of post office employees whether they are enrolled or not in a virtual 
school.

We chose the Tunisian post office because it is the first Tunisian company that has set up its own virtual school for the benefit of its employees, which would allow them improving their skills and insuring internal promotion within the post.

Data collection was conducted using a questionnaire that was administered face to face to 200 postal employees in Tunis, Sousse, Monastir, Sfax and Jendouba.

Our sample consists of 200 postal employees including $51 \%$ men and $49 \%$ women. The age of respondents varied between 20 and 60 years with a higher frequency of 30 to 39 years. The average experience of employees varies between 2 and 5 years. The sample distribution by region is described in Table 1.

Table 1. Sample distribution by region.

\begin{tabular}{cc}
\hline Region & percentages \\
\hline Tunis & $35 \%$ \\
Sousse & $25 \%$ \\
Monastir & $15 \%$ \\
Sfax & $20 \%$ \\
Jendouba & $5 \%$ \\
\hline
\end{tabular}

\subsection{Measures}

The survey instrument for this study was designed from existing scales in information systems research of TAM. These scales were translated from English to French using the method of the Committee [62]. The questionnaire consists of 31 items and measured by a Likert scale ranging from 5 points "Totally agree" to "Strongly agree." To ensure the clarity of the items, the questionnaire was pre-tested with twenty employees. No difficulty in understanding the items was observed and therefore no changes have been introduced during the pre-test phase.

The final items are listed in Table 2 with their sources.

\section{Data Analysis and Results}

The data analysis process followed a two-step approach for a Structural Equation method recommended by Anderson and Gerbing [70]. In the first step, exploratory and confirmatory factor analyses were used to assess the dimensionality, reliability and validity of constructs. In the second step, to explore the causal relationships among all constructs, the structural model for the research model was tested using a Structural Equation Method with a software program called Analysis of

Table 2. Construct measurement and sources.

Perceived usefulness
(PU)

PU1: Using the e-learning system improves my learning performance.

PU2: Using the e-learning system enhances my learning effectiveness.

PU3: Using the e-learning system gives me greater control over learning.

PU4: I find the e-learning system to be useful in my learning.

PEOU1 Interacting with the e-learning system does not require a lot of my mental effort.

Perceived ease of use PEOU2 I find the e-learning system to be easy to use.

(PEOU) PEOU3 My interaction with the e-learning system is clear and understandable.

PEOU4 I find it easy to get the e-learning system to do what I want it to do.

VOL1 My superiors expect me to use the system.

Voluntariness of use VOL2 My use of the system is voluntary.

(VOL)

VOL3 My supervisor does not require me to use the system.

Although it might be helpful, using the system is certainly not compulsory in my job.

Technics Assistance TA 1 I think instructions for the proper use of e-learning are available for those who complete the training.

(TA)

TA2 In my business, e-learning specialists always lend support in case of problem to those in need.

NTICSE1 I feel comfortable using e-learning to train me.

NTICSE2 In my opinion, using the tools of e-learning is important.

NTICSE3 I can use e-learning even if there is no one by my side to show me how.

NTICSE4 For me it is important to be helped in the use of e-learning.

CQ1 I search and share the related course content from the e-learning system to help my learning.

Content quality (CQ)

CQ2 Content of the e-learning system is updated on a regular basis.

CQ3 The e-learning system often provides the updated information.

Interpersonal influence INI1 My supervisor thinks that I should use the e-learning system.

(INI)

INI2 My colleagues think that I should use the e-learning system.

$[7,45,63,53]$

$[7,45,53,63]$

$[45,63]$

$[34,64]$

$[36,65,66]$

EXI1. I read/see news reports that using the e-learning system is a good way of learning.

External influence
(EXI )

EXI3. Mass media reports convince me to use the e-learning system.

Attitude towards use ATU1 Using the e-learning system is a good idea
(ATU)

(ATU)

ATU3 Overall, I like using the e-learning system.

ITU1 I will use the e-learning system on a regular basis in the future.

Intention to use (ITU) ITU2 I will frequently use the e-learning system in the future.

ITU3 I will strongly recommend others to use the e-learning system. 
Moment Structures (AMOS 18.0).

\subsection{Factor Analysis}

To purify and assess the dimensionality of the scales, we conducted a principal components analysis (PCA) with a varimax rotation. Two items were eliminated (NTICSE4 and CQ1). These are the items with low factor loadings and whose communalities are less than 0.5. All items that we have retained have factor loadings greater than 0.6. All our measurement scales are reliable with satisfying Cronbach's alpha coefficients ranging between 0.7 and 0.85 . The appendix provides a summary of the main results of the exploratory analysis (Appendix 1).

In a second phase, we conducted a confirmatory factor analysis on AMOS 18.0 to test the reliability and validity of each measurement scale (Appendix 2).

The results of the estimation of the structural equation model of the measurement model show that convergent validity is satisfactory $(\rho v c>0.5)$. Similarly, all factor loadings are significant $(C R>1.96)$ and greater than 0.6 . The set of values of the coefficients of multiple determinations are good. Jöreskog rho was calculated for each variable. All coefficients are above the recommended threshold of 0.7 .

The methodology adopted to check discriminant validity is to make sure that each concept shares more variance with its items than with other latent variables. Specifically, we conclude that discriminant validity is verified when average variance of the variable $X$ ( $\rho v c$ of the latent variable) is greater than the square of the correlation between the variable $\mathrm{X}$ and the remaining variables.

In Table 3, the diagonal figures report the variances shared between constructs and their measurement indicators $(\rho v c)$. The rest of the table corresponds to the square of the correlation between different constructs.

All coefficients of the squared correlation are less than the average extracted variance. Therefore, discriminate validity is checked.

Finally, we tested the goodness of fit of the measurement model. Table 4 shows that the model is satisfactory because all indices have values respecting empirical standards. In fact, the model is parsimonious with a normalized Chi square and a satisfactory BIC index, signifyicant and lower than the index of the saturated model. RMR indices are lower than the empirical threshold 0.8 . Finally, absolute GFI and AGFI indices are close to 1 and are acceptable.

\subsection{Hypothesis Testing}

"Causality" links between variables of the model were analyzed by structural equation models in AMOS 18.0.

The structural equation method allowed us to confirm some relationships and to reject others. Each relationship cannot be considered significant when the value of the corresponding CR is smaller than 1.96 in absolute value. The results of the structural modeling analysis are reported in Table 5.

Table 3. Discriminant validity of the measurement model.

\begin{tabular}{|c|c|c|c|c|c|c|c|c|c|c|}
\hline & NTICSE & CQ & $\mathbf{T A}$ & EXI & INI & $\mathbf{P U}$ & PEOU & ATU & ITU & VOL \\
\hline NTICSE & 0.519 & & & & & & & & & \\
\hline CQ & 0.081 & 0.653 & & & & & & & & \\
\hline $\mathbf{T A}$ & 0.307 & 0.483 & 0.555 & & & & & & & \\
\hline INI & 0.138 & 0.147 & 0.097 & 0.222 & 0.680 & & & & & \\
\hline PU & 0.440 & 0.015 & 0.311 & 0.251 & 0.100 & 0.633 & & & & \\
\hline PEOU & 0.388 & 0.036 & 0.410 & 0.123 & 0.137 & 0.486 & 0.524 & & & \\
\hline ITU & 0.336 & 0.008 & 0.262 & 0.192 & 0.111 & 0.294 & 0.441 & 0.499 & 0.652 & \\
\hline VOL & 0.254 & 0.080 & 0.229 & 0.154 & 0.040 & 0.207 & 0.381 & 0.598 & 0.382 & 0.501 \\
\hline
\end{tabular}

Table 4. Goodness of fit of the model to measure the use of e-learning.

\begin{tabular}{cccccccc}
\hline $\mathbf{X}^{2}$ & $\mathbf{X} 2 / \mathbf{d d l}$ & GFI & AGFI & RMR & TLI & CFI & BIC \\
\hline $958.22 \mathrm{ddl}=332 \mathrm{p}=0.000$ & 2.886 & 0.885 & 0.865 & 0.055 & 0.909 & 0.903 & $1503.949 /(2304.768)$ \\
\hline
\end{tabular}


Table 5. Results of the structural modeling analysis.

\begin{tabular}{|c|c|c|c|c|c|c|c|c|c|}
\hline & & & & Regress stand & s.e & c.r & $\mathbf{P}$ & smc & \\
\hline H1 & PEOU & $<---$ & NTICSE & 0.566 & 0.041 & 6.660 & $* * *$ & 0.596 & Validated \\
\hline $\mathrm{H} 2 \mathrm{~A}$ & PEOU & $<---$ & TA & 0.524 & 0.041 & 6.089 & $* * *$ & & Validated \\
\hline H3B1 & PEOU & $<---$ & EXI & 0.069 & 0.035 & 0.951 & 0.342 & & Rejected \\
\hline H2B & PU & $<---$ & CQ & 0.359 & 0.037 & 3.021 & 0.000 & 0.691 & Validated \\
\hline H3A1 & PU & $<---$ & INI & 0.018 & 0.044 & 0.288 & 0.773 & & Rejected \\
\hline H3B2 & PU & $<---$ & EXI & 0.277 & 0.051 & 3.856 & $* * *$ & & Validated \\
\hline H4 & PU & $<---$ & PEOU & 0.682 & 0.137 & 7.421 & $* * *$ & & Validated \\
\hline H5 & ATU & $<---$ & $\mathrm{PU}$ & 0.307 & 0.066 & 2.863 & 0.004 & 0.844 & Validated \\
\hline H7 & ATU & $<---$ & PEOU & 0.676 & 0.120 & 5.196 & $* * *$ & & Validated \\
\hline H6 & ITU & $<---$ & $\mathrm{PU}$ & -0.187 & 0.138 & -1.197 & 0.231 & 0.575 & Rejected \\
\hline H8 & ITU & $<---$ & ATU & 0.857 & 0.254 & 40.852 & $* * *$ & & Validated \\
\hline H3A2 & ITU & $<---$ & INI & 0.080 & 0.042 & 1.200 & 0.230 & & Rejected \\
\hline H1B2 & ITU & $<---$ & EXI & 0.218 & 0.059 & 2.352 & 0.019 & & Validated \\
\hline
\end{tabular}

\subsection{Testing the Moderating Effect of the Variable Voluntariness}

A moderating variable is defined as "a qualitative variable (e.g., gender, social class) or quantitative (e.g., level of reward) that affect the direction and/or strength of the relationship between the independent variable and the dependent variable" [71].

The direct link between interpersonal influence and intention to use e-learning is insignificant hence $\mathrm{H} 1 \mathrm{C}$ is rejected.

The procedure to perform a multivariate group analysis and to test the moderating effect of voluntariness on the link between external influences and intention to use e-learning (H1D) is as follows:

- Create an identical model to test for the two samples.

- Link each model to its appropriate database.

- Create a fixed or constrained model in which we assume that factor loadings for both are the same; and an unconstrained or free variant model in which we assume that the loadings vary by group.

- Test the difference in the factor loadings between the two groups.

\section{Step 1: Identification of groups}

Since our moderating variable is ordinal, we divided it into two groups by transforming this variable into a dichotomous variable using the classification method (dynamic clouds). Ultimately, we have two groups: group 1 e-learning users by requirement and group 2: volunteer e-learning users.

Results (Table 6) indicate that $50 \%$ of the sample be-
Table 6. Segmentation of the sample according to voluntariness level.

\begin{tabular}{ccc}
\hline Classes & Number & Percentage \\
\hline Group 1: user by requirement & 100 & $50 \%$ \\
Group 2: volunteer users & 100 & $50 \%$ \\
Total & 200 & $100 \%$ \\
\hline
\end{tabular}

longs to the first group and 50\% belong to the second group.

\section{Step 2: Test results of the chi-square difference}

We notice that the unconstrained model has a nonsignificant chi-square coefficient equal to 11.899 with 22 degrees of freedom $(p=0.063>0.05)$, whereas the constrained model has a chi-square coefficient of 28.773 with 17 degrees of freedom which is significant $(\mathrm{p}=$ $0.015)$.

The chi-square difference between the free model and the constrained model is significant, $p=0.021$ below the 0.05 threshold. Then, we may conclude that voluntaryness moderates the relationship between external influences and intention to use e-learning.

Step 3: Specifications of the moderator variable: voluntariness

At this level, it seems appropriate to consider whether the nature and intensity of the moderating role of volunteerism in the relationship between external influences and intention to use e-learning varies from one group to another. The results are obtained by comparing the standardized coefficients for each of the two groups (Table 
7).

With reference to Table 7, we may conclude that the moderating impact of volunteerism on the relationship between external influences and intention to use elearning is significant for both groups. Indeed T-Student test is significant and greater than 2 and probability level of the coefficient is less than $5 \%$.

However, we notice that the dampening effect of voluntariness is quite intense for the first group. Differently put, the relationship between external influences and intention to use an e-learning system is more intense among employees required by their companies to use elearning.

\section{Discussion and Implications}

Structural links between perceived ease of use (PEOU) and mastery of new technologies of information and communication (NTICE), and also between perceived ease of use (PEOU) and Technics assistance are proved significant $(\mathrm{t}=6.660,6.089, \mathrm{p}=0.000)$. Furthermore, these relationships are positive in nature and very close in terms of intensity ( $\gamma=0.566$ and $\gamma=0.524)$.

Then NTIC self-efficacy (NTICSE) as an individual variable and technics assistance (TA) as an organizational variable appear to be two key factors for the acceptance of e-learning. The results support prior research (e.g. $[8,15,48,50,57])$. This implies the need for practitioners and human resource managers to conduct training in the use and mastery of current technologies, primarily the use of computers, the Internet and intranets, but also to ensure that they assist their employees by providing them with help and advice.

As for social factors, our research finds no significant relationship between interpersonal influences (INI) and intention or perceived usefulness of e-learning $(t=1.2$; $0.288 ; \mathrm{p}=1.2 ; \gamma=0.773)$. This result is consistent with that of Davis et al. [7] and Mathieson [33] who found no impact of subjective norms on intention. These authors explain that lack of relationship does not mean that subjective norms have no effect, but that this effect can be complex and acts only in some specific situations. Thus, the reference group of a Tunisian employee, composed of his/her colleagues and superiors, appears to have no effect on perceived usefulness of e-learning and his/her intention to use e-learning.

However, intrapersonal influences as subjective norms

Table 7. Analysis of multi-group moderating effect of voluntariness

\begin{tabular}{cccccccc}
\hline Group & \multicolumn{6}{c}{ Group 1: users by requirement } & Group 2: volunteer users \\
\hline & Std Reg & T & P & Std Reg & T & P \\
ITU IEX & 0.694 & 3.101 & 0.000 & 0.260 & 2.007 & 0.048 \\
\hline
\end{tabular}

were found to positively affect intention to use the system directly $(\mathrm{t}=2.352 ; \mathrm{p}=0.019, \gamma=0.218)$ and indirectly via PU $(t=3.856 ; p=0.000, \gamma=0.277)[15,32,37]$ but has no significant effect on PEOU $(\mathrm{t}=0.951 ; \mathrm{p}=$ 0.342). Likewise, it seems that the direct and positive influence of EXI on intention to use e-learning depends on whether the adoption of the latter is voluntary or mandatory [43]. Indeed, the effect of EXI on intention to use e-learning is more important for Tunisian post office employees whose adoption of e-learning is involuntary. Thus, the Tunisian employee seems to be more sensitive to the opinion of his/her reference group formed by mass media and experts when adopting the system is rather mandatory $[15,32,37]$.

As for system factors, the effect of the content quality of e-learning on perceived usefulness is significant and positive $(\mathrm{t}=3.021, \mathrm{p}=0.000)$, which is consistent with the results of Lee [8] and Pituch and Lee [72]. In fact, the more the content of e-learning is good-quality, rich and updated regularly, the more perceived usefulness is important $[8,46]$.

Finally, Tunisian employees, attitude towards the use of e-learning (ATU) seem to be a key determinants and very important for its use $(\gamma=0,857)$ [7,15,70,73-76]. Similarly, our research has shown the importance of the direct positive influence of perceived ease of use of elearning on attitudes towards this latter $(t=5.196 ; \mathrm{p}=$ $0.000, \gamma=0.676)$ but also indirectly through perceived usefulness $(t=7.421 ; p=0.000, \gamma=0.682)$. Finally, the influence of perceived usefulness on attitude $(\gamma=0307)$ is less important than perceived ease of use $(\gamma=0676)$.

\section{Conclusions}

Our research shows that intention to use e-learning in the Tunisian context depends on the positive attitude of employees towards e-learning. This positive attitude is explained primarily by good perceptions of ease of use and usefulness, second by their perceptions of their ability to master new information technologies (NICT) and Technics assistance (TA) proposed by the company, and finally by the content quality (CQ) of training and extra personal influences (EXI).

The moderating role of voluntariness on the relationship between external influences and intention to use e-learning has been confirmed. Indeed, it turns out that this relationship is stronger for employees whose adoption of e-learning is not voluntary than those whose use is voluntary and indicates on the other hand the importance of the three variables.

The results of our research confirm that acceptance of e-learning by Tunisian employees depends primarily on their relationship with new information technologies. In fact, their deception is being unable to master the training tool, not to be well assisted at all levels of training and 
experience difficulties when using the latter. Indeed, elearning in Tunisia is still in its infancy and the Tunisian employee is not yet accustomed to this new form of training without doubting its effectiveness and its importance.

\subsection{Managerial Implications}

On the managerial level, the outcome of this research allows us to make recommendations to training managers to promote the use of e-learning.

Thus, we propose that managers should focus on training employees in the use of computer tools in general and Internet and intranet in particular, so that they can develop computer fluency and a strong sense of personal computer efficacy. Particular attention should also be paid to the ease and simplicity of handling e-learning systems on the part of employees.

So we encourage managers to establish periodic upgrading sessions in favour of the unit responsible for the administration of e-learning within the company and all those who are able to assist employees, either on a technical level or by advice and use instructions. Moreover, we suggest that managers continuously improve the quality of training content, as the incorporation of pleasure in learning content presents the greatest challenge to instructors who do not have sufficient computer skills [46].

\subsection{Limitations}

This study has limitations that should be noted and addressed in all future research. This study was limited to the sector of the Tunisian post office. Given the limited scope of this study, caution should be taken in generalizing the results. Indeed, respondents in this study are of Tunisian culture and certainly their cultural beliefs influenced their perceptions, attitudes and intentions. Similarly, it is important to understand how the influence of these factors changes over time with the mastery of the use of e-learning by employees.

\subsection{Future Research}

It would be interesting in future research to integrate cultural variables in the technology acceptance model of e-learning. Variables like, for example, the characteristics of national cultures postulated by Geert Hofstede (individualism, collectivism, masculinity, femininity, power distance and uncertainty avoidance) in order to enrich the study of cultural differences in the use of e-learning. But also a comparative study which highlights the difference of the determinants of e-learning acceptance between developing countries (like Tunisia) and developed countries.

It would also be appropriate to conduct a longitudinal study to observe the variation of the evolution of e- learning acceptance and usage over time and try to explain it.

\section{REFERENCES}

[1] C. Ho and R. Dzeng, "Construction Safety Training via E-Learning: Learning Effectiveness and User Satisfaction," Computers \& Education, Vol. 55, No. 2, 2010, pp. 858-867. doi:10.1016/j.compedu.2010.03.017

[2] W. T. Wong and N. T. N. Huang, "The Effect of ELearning System Service Quality and Users' Acceptance on Organizational Learning," International Journal of Business and Information, Vol. 6, No. 2, 2011, pp. 205225.

[3] K. Tyler, "E-Learning Not Just for Enormous Companies Anymore," HR Magazine, Vol. 4, No. 5, 2001, pp. 82-88.

[4] A. Vicere, "Ten Observations about E-Learning and Leadership Development," Human Resource Planning, Vol. 23, No. 4, 2000, pp. 34-46.

[5] C. Gueye and S. Boussaguet, "Management des Connaissances: Une Approche en Termes de Création de Valeur," Les actes du colloque de l'IAS, Toulouse, 30-31 Aout 2001, pp. 91-97.

[6] M. Thevenet, "Approches de la Formation Continue en Entreprise," Revue Française de Gestion, Vol. 54, No. 65-66, 1987, pp. 61-69.

[7] F. D. Davis, R. P. Bagozzi and P. R. Warshaw, "User Acceptance of Computer Technology: A Comparison of Two Theoretical Models," Management Science, Vol. 35, No. 8, 1989, pp. 982-1003. doi:10.1287/mnsc.35.8.982

[8] Y. C. Lee, "An Empirical Investigation into Factors Influencing the Adoption of an E-Learning System," Online Information Review, Vol. 30, No. 5, 2006, pp. 1468-4527. doi:10.1108/14684520610706406

[9] W. Minhong, "Integrating Organizational, Social, and Individual Perspectives in Web 2.0-Based Workplace ELearning," Information Systems Frontiers, Vol. 13, No. 2, 2009, pp. 191-252.

[10] P.-C. Sun, R. J. Tsai, G. Finger, Y.-Y. Chen and D. Yeh. "What Drives Successful E-Learning? An Empirical Investigation of the Critical Factors Influencing Learner Satisfaction," Computers and Education, Vol. 50, No. 4, 2006, pp. 1183-1202.

doi:10.1016/j.compedu.2006.11.007

[11] S. Mackay and G. Stockport, "Blended Learning, Classroom and E-Learning," The Business Review Cambridge, Vol. 5, No. 1, 2006, pp. 82-87.

[12] P. Roussel, “Pour un Développement de L'e-Formation Dans le Prolongement du E-Management," Les Notes du LIRHE, No 354, 2001. http://www.univ-tlsel .fr/lirhe/J

[13] M. C. Lee, 'Explaining and Predicting Users' Continuance Intention toward E-Learning: An Extension of the Expectation-Confirmation Model," Computers \& Education, Vol. 54, No. 2, 2010, pp. 506-516. doi:10.1016/j.compedu.2009.09.002

[14] S. Hrastinski, "The Potential of Synchronous Communication to Enhance Participation in Online Discussion," 28th International Conference on Information Systems, 
Montreal, 9-12 December 2007, pp. 102-112.

[15] Y. M. Cheng, "Antecedents and Consequences of ELearning Acceptance," Information System Journal, Vol. 21, 2011, pp. 269-299.

doi:10.1111/j.1365-2575.2010.00356.x

[16] M. Favier, M. Kalika and J. Trahand, "E-Learning/EFormation: Implication Pour les Organisations," Systèmes d'Information et Management, Vol. 9, No. 4, 2004, pp. 55-65.

[17] R. Meissonier and E. Houzé, "Performance du E-Learning: Un Premier Retour D'expérience sur les Résultats des Apprenants," 9ème Colloque de L'Association Information et Management, Evry, 26-28 May 2004, pp. 67-87.

[18] D. Carl, "Electronic Distance Education: Positives Outweigh Negatives," Technological Horizons in Education, Vol. 18, No. 10, 1991, pp. 67-71.

[19] M. J. Rosenberg, "E-Learning: Strategies for Delivering Knowledge in the Digital Age," McGraw-Hill, New York, 2001.

[20] M. Mingasson, "Le Guide du E-Learning: L'organisation Apprenante," Editions d'Organisation, Paris, 2002.

[21] C. Collins, D. Buhalis and M. Peters, "Enchancing SMEs' Business Performance through the Internet and E-Learning Platforms," Education and Training, Vol. 45, No. 8-9, 2003, pp. 483-494. doi:10.1108/00400910310508874

[22] K. Vaughan and A. Mac Vicar, "Employees Pre-Implementation Attitudes and Perceptions to E-Learning: A Banking Case Study Analysis," Journal of European Industrial Training, Vol. 28, No. 5, 2004, pp. 400-413. doi:10.1108/03090590410533080

[23] M. N. Tahir, "E-Learning in Public Organizations," Public Personnel Management, Vol. 33, No. 1, 2004, pp. 7988.

[24] J. O. Uhomoidhi, "Implementing E-Learning in Northern Ireland: Prospects and Challenges," Campus-Wide Information Systems, Vol. 23, No. 1, 2006, pp. 4-14. doi:10.1108/10650740610639697

[25] J. C. R. Tseng, W. L. Tsai, G. J. Hwang and P. H. Wu, "An Efficient and Effective Approach to Developing Engineering E-Learning Courses," Journal of Distance Education Technologies, Vol. 5, No. 1, 2007, pp. 37-53. doi:10.4018/jdet.2007010104

[26] D. Zhang and L. Zhou, "Enhancing E-Learning with Interactive Multimedia," Information Resources Management Journal, Vol. 16, No. 4, 2003, pp. 1-14. doi:10.4018/irmi.2003100101

[27] Z. S. Imamoglu, "An Empirical Analysis Concerning the User Acceptance of E-learning," Journal of American Academy of Business Cambridge, Vol. 11, No. 1, 2007, pp. 132-137.

[28] T. Oppenheimer, "The Computer Delusion," Atlantic Monthly, Vol. 280, No.1, 1997, pp. 45-62.

[29] R. Kraut, V. Lundmark, S. Patterson, S. Kiesler and W. Scherlis, "Internet Paradox: A Social Technology That Reduces Social Involvement and Psychological Wellbeing," American Psychologist, Vol. 53, No. 3, 1998, pp. $39-43$.
[30] F. D. Davis, "Perceived Usefulness, Perceived Ease of Use and User Acceptance of Information Technology," MIS Quarterly, Vol. 13, No. 3, 1989, pp. 319-340. doi: $10.2307 / 249008$

[31] C. C. Bienstock, M. B. Royne, D. Sherrell and T. F. Stafford, "An Expanded Model of Logistics Service Quality: Incorporating Logistics Information Technology," International Journal of Production Economics, Vol. 113, No. 1, 2008, pp. 205-222. doi:10.1016/j.ijpe.2007.03.023

[32] V. Venkatesh and F. D. Davis, "A Theoretical Extension of the Technology Acceptance Model: Four Longitudinal Studies," Management Science, Vol. 46, No.2, 2000, pp. 186-204. doi:10.1287/mnsc.46.2.186.11926

[33] K. Mathieson, "Predicting User Intention: Comparing Technology Acceptance Model with the Theory of Planned Behavior," Information System Research, Vol. 2, No. 3, 1991, pp. 173-191. doi:10.1287/isre.2.3.173

[34] R. L. Thompson, C. A. Higgins and J. M. Howell, "Personnel Computing: Toward a Conceptual Model of Utilization," MIS Quarterly, Vol. 15, No. 1, 1991, pp. 125-143. doi: $10.2307 / 249443$

[35] V. Venkatesh and F. D. Davis, "A Model of the Antecedents of Perceived Ease of Use, Development and Test," Decision Sciences, Vol. 27, No. 3, 1996, pp. 451-481. doi:10.1111/j.1540-5915.1996.tb01822.x

[36] M. Fishbein and I. Ajzen, "Belief, Attitude, Intention, and Behavior: An Introduction to Theory and Research," Addison-Wesley, Reading, 1975.

[37] E. M. Van Raaij and J. J. L. Schepers, "The Acceptance and Use of a Use Virtual Learning Environment in China," Computer \& Education, Vol. 50, No. 3, 2008, pp. 838-852. doi:10.1016/j.compedu.2006.09.001

[38] S. Taylor and P. A. Todd, "Understanding Information Technology Usage: A Test of Competing Models," Information System Research, Vol. 6, No. 2, 1995, pp. 144176. doi:10.1287/isre.6.2.144

[39] A. Bhattacherjee, "Acceptance of Internet Applications Services: The Case of Electronic Brokerages," IEEE Transactions on Systems, Man and Cybernetics-Part A: Systems and Humans, Vol. 30, No. 4, 2000, pp. 411-420. doi: $10.1109 / 3468.852435$

[40] C. L. Hsu and H. P. Lu, "Why Do People Play On-Line Games? An Extended TAM with Social Influences and Flow Experience," Information \& Management, Vol. 41, No. 7, 2004, pp. 853-868. doi:10.1016/j.im.2003.08.014

[41] E. M. Van Raaij and J. J.-L. Schepers, "The Acceptance and Use of a Use Virtual Learning Environment in China," Computer \& Education, Vol. 50, No. 3, 2008, pp. 838-852. doi:10.1016/j.compedu.2006.09.001

[42] H. Barki and J. Harwick, "Measuring User Participation, User Involvement and User Attitude," MIS Quarterly, Vol. 18, No. 1, 1994, pp. 59-82. doi:10.2307/249610

[43] V. Venkatesh, M. G. Morris and G. B. Davis, "User Acceptance of Information Technology: Toward a Unified View," MIS Quarterly, Vol. 27, No. 3, 2003, pp. 425-478.

[44] T. Lassouad, "Les Déterminants de L'adoption de L'eleaning: Etude Empirique au Sein de L'entreprise Tunisienne," Ph.D. Dissertation, Université Jean Moulin Lyon 
3, France, 2010.

[45] V. Venkatesh, "Determinants of Perceived Ease of Use: Integrating Control, Intrinsic Motivation and Emotion into the Technology Acceptance Model," Information Systems Research, Vol. 11, No. 4, 2000, pp. 342-365. doi:10.1287/isre.11.4.342.11872

[46] B. C. Lee, J. O. Yoon and I. Lee, "Learners' Acceptance of E-Learning in South Korea: Theories and Results," Computers \& Education, Vol. 53, No. 4, 2009, pp. 320329. doi:10.1016/j.compedu.2009.06.014

[47] A. Bandura, "Social Foundations of Thought and Action," Prentice-Hall, Englewood Cliffs, 1986.

[48] J. C. Roca, C. M. Chiu and F. J. Martínez, "Understanding E-Learning Continuance Intention: An Extension of the Technology Acceptance Model," International Journal of Human-Computer Studies, Vol. 64, No. 8, 2006, pp. 683-696. doi:10.1016/j.ijhcs.2006.01.003

[49] I. T. J. Brown, "Individual and Technological Factors Affecting Perceived Ease of Use of Web-Based Learning Technologies in Developing Country," The Electronic Journal of Information Systems in Developing Countries, Vol. 9, No. 5, 2002, pp. 1-15.

[50] C. S. Ong, J. Y. Lai and Y. S. Wang, "Factors Affecting Engineers' Acceptance of Asynchronous E-Learning Systems in High-Tech Companies," Information \& Management, Vol. 41, No. 6, 2004, pp. 795-804. doi:10.1016/j.im.2003.08.012

[51] P. Legris, J. Ingham and P. Collerette, "Why Do People Use Information Technology? A Critical Review of the Technology Acceptance Model," Information \& Management, Vol. 40, No. 3, 2003, pp. 191-204. doi:10.1016/S0378-7206(01)00143-4

[52] L. Stoel and K. H. Lee, "Modelling the Effect of Experience on Student Acceptance of Web-Based Courseware," Internet Research, Vol. 13, No. 5, 2003, pp. 364-374. doi:10.1108/10662240310501649

[53] E. W. T. Ngai, J. K. L. Poon and Y. H. C. Chan, "Empirical Examination of Adoption of Web CT Using TAM," Computers and Education, Vol. 48, No. 2, 2007, pp. 250-267. doi:10.1016/j.compedu.2004.11.007

[54] S. H. Liu, H. L. Liao and J. A. Pratt, "Impact of Media Richness and Flow on E-Learning Technology Acceptance," Computers \& Education, Vol. 52, No. 3, 2009, pp. 599-607. doi:10.1016/j.compedu.2008.11.002

[55] M. K. O. Lee, C. M. K. Cheung and Z. Chen, "Acceptance of Internet-Based Learning Medium: The Role of Extrinsic and Intrinsic Motivation," Information \& Management, Vol. 42, No. 8, 2005, pp. 1095-1104. doi:10.1016/j.im.2003.10.007

[56] R. Saadé and B. Bahli, "The Impact of Cognitive Absorption on Perceived Usefulness and Perceived Ease of Use in On-Line Learning: An Extension of the Technology Acceptance Model," Information \& Management, Vol. 42, No. 2, 2005, pp. 317-327. doi:10.1016/j.im.2003.12.013

[57] C. S. Ong and J. Y. Lai, "Gender Differences in Perceptions and Relationships among Dominants of E-Learning Acceptance," Computers in Human Behavior, Vol. 22, No. 5, 2006, pp. 816-829. doi:10.1016/j.chb.2004.03.006
[58] Y. C. Lee, "The Role of Perceived Resources in Online Learning Adoption," Computers \& Education, Vol. 50, No. 4, 2008, pp. 1423-1438. doi:10.1016/j.compedu.2007.01.001

[59] J. C. Roca and M. Gagné, "Understanding E-Learning Continuance Intention in the Workplace: A Self Determination Theory Perspective," Computers in Human Behavior, Vol. 24, No. 4, 2008, pp. 1585-1604. doi:10.1016/j.chb.2007.06.001

[60] P. D. Chatzoglou, L. Sarigiannidis, E. Vraimaki and E. Diamantidis, "Investigating Greek Employees' Intention to Use Web-Based Training," Computers \& Education, Vol. 53, No. 3, 2009, pp. 877-889. doi:10.1016/j.compedu.2009.05.007

[61] N. O. Ndubisi, "Factors of Online Learning Adoption: A Comparative Juxtaposition of the Theory of Planned Behaviour and the Technology Acceptance Model," International Journal on E-Learning, Vol. 5, No. 4, 2006, pp. 571-591.

[62] L. G. Vallerand, "Vers une Methodologie de Validation Transculturelles des Questionnaires Psychologiques: Implications Pour la Recherche en Langue Française," Psychologie Canadienne, Vol. 30, No. 4, 1989, pp. 662-680.

[63] V. Venkatesh and F. D. Davis, "A Theoretical Extension of the Technology Acceptance Model: Four Longitudinal Studies," Management Science, Vol. 46, No. 2, 2000, pp. 186-204. doi: $10.1287 / \mathrm{mnsc} .46 .2 .186 .11926$

[64] N. Schillewaert, M. J. Ahearne, R. T. Frambach and R. K. Moenaert, "Acceptance of Information Technology in the Sales Force," E-Business Research Centre, The Pennsylvania State, 2001.

[65] D. Compeau, C. A. Higgins and S. Huff, "Computer SelfEfficacy: Development of a Measure and Initial Test," MIS Quarterly, Vol. 19, No. 2, 1995, pp. 189-211. doi: $10.2307 / 249688$

[66] S. Guerrero, "Contribution à l'Efficacité du E-Learning," Colloque de l'IAS, Toulouse, 30-31 August 2001, pp. 161-167.

[67] J. B. Arbaugh, "Virtual Classroom Characteristics and Student Satisfaction with Internet-Based MBA," Journal of Management Education, Vol. 24, No. 1, 2000, pp. 3254. doi:10.1177/105256290002400104

[68] I. Ajzen and M. Fishbein, "Understanding Attitudes and Predicting Social Behavior," Prentice-Hall Inc, Englewood Cliffs, 1980

[69] A. Bhattacherjee, "An Empirical Analysis of the Antecedents of Electronic Commerce Service Continuance," Decision Support Systems, Vol. 32, No. 2, 2001, pp. 201214. doi:10.1016/S0167-9236(01)00111-7

[70] J. C. Anderson and D. W. Gerbing, "Structural Equation Modelling in Practice: A Review and Recommended Two Step Approach," Psychological Bulletin, Vol. 103, No. 3, 1988, pp. 411-423. doi:10.1037/0033-2909.103.3.411

[71] R. M. Baron and D. A. Kenny, "The Moderator-Mediator Variable Distinction in Social Psychological Research: Conceptual, Strategic and Statistical Considerations," Journal of Personality and Social Psychology, Vol. 51, No. 6, 1986, pp. 1173-1182. doi:10.1037/0022-3514.51.6.1173 
[72] K. A. Pituch and Y. K. Lee, "The Influence of System Characteristics on E-Learning Use," Computer \& Education, Vol. 47, No. 2, 2006, pp. 222-244. doi:10.1016/i.compedu.2004.10.007

[73] C. M. Jackson, S. Chow and R. A. Leitch "Toward an Understanding of the Behavioral Intention to Use an Information System," Decision Sciences, Vol. 28, No. 2, 1997 , pp. 357-389. doi:10.1111/j.1540-5915.1997.tb01315.x

[74] E. Karahana, D. W. Straub and N. L. Chervany, "Information Technology Adoption across Time: Across Sectional Comparison of Pre-Adoption and Post-Adoption
Beliefs," MIS Quarterly, Vol. 23, No. 2, 1999, pp. 183213. doi: $10.2307 / 249751$

[75] M. Igbaria and M. Tan, "The Consequences of Information Technology Acceptance on Subsequent Individual Performance," Information \& Management, Vol. 32, No. 3, 1997, pp. 113-121. doi:10.1016/S0378-7206(97)00006-2

[76] R. P. Bagozzi, "On the Concept of Intentional Social Action in Consumer Behavior," Journal of Consumer Research, Vol. 27, No. 3, 2000, pp. 388-396.

doi: $10.1086 / 317593$ 


\section{Appendix 1}

Exploratory factor analysis results

Measurement scale 1: Mastery of ICT

$\mathrm{KMO}=0.668 ;$ rounded Chi square $=126.609 ; \mathrm{Ddl}=3$ significance of Bartlett $=0.000$. Cronbach's Alpha $=0.770$

\section{MNTIC1}

MNTIC2

MNTIC3

Measurement scale 2: Cognitive storing capacity

$\mathrm{KMO}=0.500 ;$ rounded Chi square $=118.857 ; \mathrm{Ddl}=1$ significance of Bartlett $=0.000$. Cronbach's Alpha $=0.853$

\section{CAC2}

CAC3

Measurement scale 3: Technical assistance

$\mathrm{KMO}=0.500 ;$ rounded Chi square $=32.507 ; \mathrm{Ddl}=1$ significance of Bartlett $=0.000$. Cronbach's Alpha $=0.616$

AT1

AT2

\section{Measurement scale 4: Content quality}

$\mathrm{KMO}=0.500 ;$ rounded Chi square $=61.445 ; \mathrm{Ddl}=1$ significance of Bartlett $=0.000$. Cronbach's Alpha $=0.725$

$$
\begin{aligned}
& \text { QC2 } \\
& \text { QC3 }
\end{aligned}
$$

Measurement scale 5: interpersonal influence

$\mathrm{KMO}=0.692 ;$ rounded Chi square $=168.298 ; \mathrm{Ddl}=3$ significance of Bartlett $=0.000$ Cronbach's Alpha $=0.817$

\section{IIP1}

IIP2

IIP3

Measurement scale 6: External influence

$\mathrm{KMO}=0.680 ;$ rounded Chi square $=127.544 ; \mathrm{Ddl}=3$ significance of Bartlett $=0.000$. Cronbach's Alpha $=0.777$

IEX1

IEX2
Contribution to postmen training F1

$\%$ Explained Variance $=68.711 \%$

0.860

0.865

0.757

Contribution to postmen training F1

$\%$ Explained Variance $=87.191 \%$

0.934

0.934

Contribution to postmen training F1

$\%$ Explained Variance $=72.237 \%$

0.850

0.850

Contribution to postmen training

F1

$\%$ Explained Variance $=79.185 \%$

0.890

0.890

Contribution to postmen training F1 $\%$ Explained Variance $=73.905 \%$ 0.616

0.664

0.744

Contribution to postmen training F1

$\%$ Explained Variance $=69.340 \%$

0.780

0.847

0.868 
Measurement scale 7: Perceived usefulness

$\mathrm{KMO}=0.775 ;$ rounded Chi square $=267.308 ; \mathrm{Ddl}=6$ significance of Bartlett $=0.000$. Cronbach's Alpha $=0.849$

UP1

UP2

UP3

UP4
Contribution to postmen training

$$
\text { F1 }
$$

$\%$ Explained Variance $=69.018 \%$

0.842

0.763

0.826

0.887

Measurement scale 8: Perceived ease of use

$\mathrm{KMO}=0.754 ;$ rounded Chi square $=229.368 ; \mathrm{Ddl}=6$ significance of Bartlett $=0.000$ Cronbach's Alpha $=0.822$

Contribution to postmen training F1

$\%$ Explained Variance $=68.711 \%$

FUP1

0.806

0.709

0.840

0.869

FUP4

Measurement scale 9: Attitude towards use of e-Learning

$\mathrm{KMO}=0.673 ;$ rounded Chi square $=82.432 ; \mathrm{Ddl}=3$ significance of Bartlett $=0.000$. Cronbach's Alpha $=0.710$

Contribution to postmen training F1

$\%$ Explained Variance $=63.336 \%$

0.810

0.769

0.808

AUE3

Measurement scale 10: Intention to use e-Learning

$\mathrm{KMO}=0.500 ;$ rounded Chi square $=79.401 ; \mathrm{Ddl}=1$ significance of Bartlett $=0.000$. Cronbach's Alpha $=0.783$

Contribution to postmen training F1

$\%$ Explained Variance $=82.259 \%$

IUE1

0.907

IUE2

0.907

Measurement scale 11: Willingness

$\mathrm{KMO}=0.680 ;$ rounded Chi square $=108.335 ; \mathrm{Ddl}=3$ significance of Bartlett $=0.000$.

Cronbach's Alpha $=0.755$

Contribution to postmen training

F1

$\%$ Explained Variance $=67.132 \%$

VOL1

0.824

VOL2

0.782

VOL3
0.850 


\section{Appendix 2}

Confirmatory Factor Analysis Results

\begin{tabular}{|c|c|c|c|c|c|c|c|}
\hline Construct & Item & $\begin{array}{l}\text { St. Factor Loading } \\
\text { (st. error) }\end{array}$ & $\begin{array}{l}\text { Squared multiple } \\
\text { correlation } \\
\text { SMC } \\
\end{array}$ & Critical value & $\mathbf{P}$ & $\begin{array}{c}\text { Composite reliability } \\
\text { (rhô of Jöreskog) } \\
\rho(A)>0.7 \\
\end{array}$ & $\begin{array}{c}\text { Convergent } \\
\text { validity } \\
\rho_{\mathrm{vc}}>0.5 \\
\end{array}$ \\
\hline \multirow{3}{*}{ MNTIC } & MNTIC1 & 0.743 & 0.552 & 9.973 & 0.000 & \multirow{3}{*}{0.764} & \multirow{3}{*}{0.522} \\
\hline & MNTIC2 & 0.804 & $0.646)$ & 10.706 & 0.000 & & \\
\hline & MNTIC3 & 0.609 & 0.371 & 8.304 & 0.000 & & \\
\hline \multirow{3}{*}{ IIP } & IIP1 & 0.694 & 0.481 & 10.655 & 0.000 & \multirow{3}{*}{0.863} & \multirow{3}{*}{0.679} \\
\hline & IIP2 & 0.872 & 0.761 & 14.183 & 0.000 & & \\
\hline & IIP3 & 0.892 & 0.795 & 14.613 & 0.000 & & \\
\hline \multirow[t]{3}{*}{ IEX } & IEX1 & 0.723 & 0.522 & 9.917 & 0.000 & \multirow{3}{*}{0.771} & \multirow{3}{*}{0.530} \\
\hline & IEX2 & 0.675 & 0.455 & 9.293 & 0.000 & & \\
\hline & IEX3 & 0.782 & 0.612 & 10.687 & 0.000 & & \\
\hline \multirow{4}{*}{ UP } & UP1 & 0.774 & 0.599 & 12.346 & 0.000 & \multirow{4}{*}{0.873} & \multirow{4}{*}{0.634} \\
\hline & UP2 & 0.719 & 0.516 & 11.147 & 0.000 & & \\
\hline & UP3 & 0.820 & 0.672 & 13.400 & 0.000 & & \\
\hline & UP4 & 0.863 & 0.744 & 14.433 & 0.000 & & \\
\hline \multirow{4}{*}{ FUP } & FUP1 & 0.599 & 0.359 & 8.658 & 0.000 & \multirow{4}{*}{0.819} & \multirow{4}{*}{0.537} \\
\hline & FUP2 & 0.626 & 0.392 & 9.147 & 0.000 & & \\
\hline & FUP3 & 0.845 & 0.714 & 13.326 & 0.000 & & \\
\hline & FUP4 & 0.827 & 0.684 & 12.960 & 0.000 & & \\
\hline \multirow{3}{*}{ AUE } & AUE1 & 0.687 & 0.471 & 9.551 & 0.000 & \multirow{3}{*}{0.777} & \multirow{3}{*}{0.538} \\
\hline & AUE2 & 0.765 & 0.586 & 10.610 & 0.000 & & \\
\hline & AUE3 & 0.747 & 0.558 & 10.366 & 0.000 & & \\
\hline \multirow{3}{*}{ VOL } & VOL1 & 0.760 & 0.577 & 10.023 & 0.000 & \multirow{3}{*}{0.752} & \multirow{3}{*}{0.503} \\
\hline & VOL2 & 0.709 & 0.503 & 9.431 & 0.000 & & \\
\hline & VOL3 & 0.657 & 0.431 & 8.803 & 0.000 & & \\
\hline
\end{tabular}

